Franklin, J. 1823, Narrative of a journey to the shores of thhe Polar Sea, in the years $1819,20,21$ and 22. John Murray, London, pp. $185-86,670$ and 679 .

Harmon, D. W. 1820. A journal of voyages and travels in the interior of North America. Flagg and Gould, Andover, p. 91.

Hearne, S. 1795. A journey from Prince of Wales Fort in Hudson's Bay, to the Northern Ocean in $1769,1770,1771$ and 1772 . A. Strahan and T. Cadell, London, pp. 417-18.

Henry, A. (the younger). 1897. New light on the early history of the great North-west: the manuscript journals of Alexander Henry and of David Thompson. Edited by Elliott Coues. Francis P. Harper, New York, pp. 469 and 622 .

Hind, H. Y. 1860. Narrative of the Canadian Red River exploring expedition of 1857 , and of the Assiniboine and Saskatchewan exploring expedition of 1858. Longman, Green, Longman and Roberts, London. Vol. I, pp. 378 and 393.

Houston, C. S. 1949. The birds of the Yorkton district, Saskatchewan. Can. Field-Nat., 63 : 230 .

Houston, C. S, and M. G. Street. 1959. The birds of the Saskatchewan River, Carlton to Cumberland. Sask. Nat. Hist. Soc., Spec. Pub. 2, pp. 100-101.

Humphry, S. 1932. Mourning Doves. Can. Field-Nat., $46: 68$.

Kelsey, H. 1929. The Kelsey papers, with an introduction by A. G. Doughty and C. Martin. Public Archives of Canada, Ottawa, p. 7.

King, R. 1836. Narrative of a jounrey to the shores of the Arctic Ocean in 1833, 1834 and 1835. Richard Bentley, London, pp. 59 and 220.

Klaus, J. F. 1962. Fort Livingstone. Sask. History, $15: 93-110$.

Macoun, J. 1882. Manitoba and the great North-West. World Publishing Co., Guelph, p. 361 .

Macoun, J. 1922. Autobiography of John Macoun, M.A., Canadian explorer and naturalist. Ottawa Field-Naturalists Club, Ottawa, pp. 190-192.

Macoun, J., and J. M. Macoun. 1909. Catalogue of Canadian birds. Geological Survey Branch, Dept of Mines. Ottawa, pp. 235-38.

McDonald, A. 1872. Peace River. A canoe voyage from Hudson's Bay to the Pacific, by the late Sir George Simpson. Journal of the late chief factor, Archibald McDonald. Edited by Malcolm McLeod. J. Durie \& Son, Ottawa, p. 6.

Mellwraith, T. 1884. Birds of Ontario. William Briggs, Toronto.

Potter, L. B. 1930. Bird life changes in twentyfive years in southwestern Saskatchewan. Can. Field-Nat., $44: 148$.

Roberts, T. S. 1936. The birds of Minnesota. Uni. of Minnesota Press, Minneapolis, $p$. 574.

Schorger, A. W. 1955. The Passenger Pigeon. Univ. of Wisconsin Press, Madison, $424 \mathrm{pp}$.

Selwyn. A. R. C. 1875. Notes on a journey through the Northwest Territory, from Manitoba to Rocky Mountain House. Can. Naturalist Geologist, n.s., $7: 200$.

Smith, H. C., and R. S. Kidd. 1971. A record of the Passenger Pigeon in Alberta. Can. Field--Nat., $85: 259$.

Southesk [J. Carnegie], Ear] of, 1875. Saskatchewan and the Rocky Mountains. Edmonston and Douglas, Edinburgh, p. 58.

Swainson, W., and J. Richardson. 1832. Fauna Boreali-Americana, Vol. 2, The birds. John Murray, London, p. 363.

Thompson, E. E. 1886. The birds of western Manitoba. Auk., $3: 153$.

Thompson, E. E. 1890. The birds of Manitoba. Proc. U.S. Nat. Museum, $13: 522-23$.

Thompson, E. E. 1893. Additions to the list of Manitoba birds. Auk., 10:49.

Todd, W E. C. 1947. Notes on the birds of southern Saskatchewan. Annals Carnegie Museum, 30:404-05.

Whillans, J. W. 1955. First in the west-the story of Henry Kelsey. Applied Art Products, Edmonton, p. 75 .

\title{
TWO NEW RECORDS OF THE VARIED THRUSH IN MANITOBA
}

\section{by Norman Lee, R.R. 3, Selkirk, Manitoba}

About 6:30 p.m. on October 9, 1971, while I was watching a group of seven robins in my yard near Lockport, 23 miles north of Winnipeg, my attention was caught by one "Robin" which had a bright orange-red breast instead of the usual brick-red or washed out red. A closer look revealed a black band running across its breast. By then I was pretty sure that this was a Varied Thrush. I immediately went for The Birds of Canada by Earl Godfrey (1966) for an exact description.
Meanwhile my brother Jack watched the bird take a bath, then followed it to a crab-apple tree where it fed with robins on fallen crab-apples. He noted a thick orange-red eye line and two distinct orange wing bars on each wing and less noticeable orange lines along the primaries. The bird flew off following an alarmed robin and was not seen for the rest of the evening.

A search took place the next morning from $7: 30$ to $8: 30$ a.m. and again at 9:00 a.m. with Herb Copland. 
Though there was a careful watch for it the rest of the day, the bird still wasn't sighted. Then, five minutes after Herb left, about 6:05 p.m. it reappeared with some robins and took a bath. This time my brother Eric was around and due to better lighting conditions, we had a much better look at it.

It did not show up again until the next evening (October 11) when it was once again with a group of robins and taking a bath. It stayed for only a few minutes then left. This was the last sighting.

Another sighting of a Varied Thrush was made December 19, 1971 at Miami, about 90 miles southwest of Winnipeg by Norm and Madeleine Cleveland. Norm reported (pers. corres.): "a beautiful male bird, sitting in a cherry tree. He took some red cherries off the tree and flew to a nearby hedge to eat them, then came back. I went to get my wife and when we got back he had moved up into a maple tree where we observed him for about another five minutes."

Jack Westaway, in whose yard the observation was made, said the Varied 'Thrush had been present there for two or three weeks prior to December 19 but he had not realized the importance of this rare visit. Although Jack has fed birds for years and is an ardent bird lover, he is not a bird identifier and was informed that it was a Varied Thrush by a Mrs. Criddle, also of Miami. After being advised of the sighting by Norm Cleveland, Herb Copland and David Hatch drove to Miami on December 22 and observed the bird for several hours (Gardner, 1972b).

Mr. Westaway left Miami during the Christmas season. The Varied Thrush did not reappear after he returned.

A review of all the known records of the Varied Thrush in Manitoba was made by Ken Gardner (1972a). "The first recorded sightings of the Varied Thrush in Manitoba go back to 1929 when one was seen at Rathwell during the summer and another in Winnipeg in mid-October. Both were seen in the company of robins.

"Miss M. E. Jollow of Brandon reported a female trying to build a nest there in early June, 1930. No male was seen. This sighting was verified by $B$. J. Hales. In late August, 1931, two Winnipeg birders spotted no less than three of these Thrushes at Husavick on $\mathrm{L}$ a k e Winnipeg.

"The next report comes from Killarney Lake where J. H. Kitley abserved a male and female on June 22 and 23, 1932. No more were reported until 1955 when Harold Hosford saw one in St. Vital Park, Winnipeg.

"However, it wasn't until 1965 that a specimen was obtained. This was a male that had been attending the feed tray of Mrs. M. E. Bristow in Brandon during November. This bird was verified by John Lane and was kept under observation until December 28 when it died during a cold snap. The bird was prepared as a specimen for the B. J. Hales Museum at Brandon University.

"The next sighting was made by George Gryzbowski who observed a lone male at the southeast corner of Birds Hill Provincial Park May 14, 1970."

According to Godfrey (1966) the Varied Thrush's breeding range in Canada starts at the Yukon and northwestern Mackenzie southward throughout British Columbia and southwestern Alberta. Godfrey makes no mention of this bird in Manitaba, but does mention reports in Alberta, Saskatchewan, Ontario, Quebec, and New Brunswick.

Recently, Sealy (1971) summarized all known records for Saskatchewan.

\section{LITERATURE CITED}

Gardner, K. 1972a. "Wild Wings" Jan. 1, 1972, Winnipeg Tribune.

Gardner, K. 1972b. "Wild Wings" Jan. 8, 1972, Winnipeg Tribune.

Godfrey, W. E. 1966. The birds of Canada. Nat. Mus. Can. Bull. No. 203, Biol. Ser. No. 73. Ottawa, $428 \mathrm{p}$.

Sealy, S. G. 1971. The occurrences of some western birds in Saskatchewan. Blue Jay, $29: 184-196$. 